\title{
Synthesis and characterization of $\mathrm{LiMn}_{1-\mathrm{x}} \mathrm{Ni}_{\mathrm{x}} \mathrm{O}_{2}$
}

\author{
Fengrao Lang $^{1, a}$
}

${ }^{1}$ Jilin Agricultural Science and Technology University, Jilin 132101,China

afengrao1982@163.com

Keywords: Cathode material, Stacking fault, o- $\mathrm{LiMnO}_{2}$

Abstract. Orthogonal $\mathrm{LiMnO}_{2}$ has unique characteristics, when used as a cathode material it performs excellently. This paper focuses on doping modification of their shortcomings, using sol gel preparation to make cathode materials, researching on a different scale doping effect of nickel on its performance as cathode material, XRD,SEM, charge and discharge test methods are adopted on structure characterization and electrochemical performance of the material.

\section{Introduction}

The crystal size of Orthogonal LiMnO2 is small, which shows the characteristic of high capacity. stacking fault shows the advantage of Cycle Performance. But there are still some troubles such as synthesis and stacking fault. Thus, our research of changing its characteristic chose the way of mixing Ni element .

Put $\mathrm{Li}\left(\mathrm{CH}_{3} \mathrm{OO}\right) \cdot 2 \mathrm{H}_{2} \mathrm{O} 、 \mathrm{Mn}(\mathrm{Ac})_{2} \cdot 4 \mathrm{H}_{2} \mathrm{O} 、 \mathrm{Ni}(\mathrm{NO} 3)_{2} \cdot 6 \mathrm{H}_{2} \mathrm{O}$ at the RRB $1.05: 1-\mathrm{x}: \mathrm{x},(\mathrm{x}=0.06,0.07$, 0.08) in the citric acid. Then, heat and mix until it becomes neutral solution. When we get the gel, put it into empty space for drying about 10 hours. Fire the presoma for 6 hours at the temperature of $400^{\circ} \mathrm{C}$. Then, put the material into the agate mortar and grind for hours, so that it can be mixed thoroughly and its particles can be small. Then, continue to fire it about 20 hours at the temperature $400^{\circ} \mathrm{C}$. Cool down to room temperature naturally, the final objective product $\mathrm{LiMn}_{1-\mathrm{x}} \mathrm{Ni}_{\mathrm{x}} \mathrm{O}_{2}$ is got .

\section{Experimental Details}

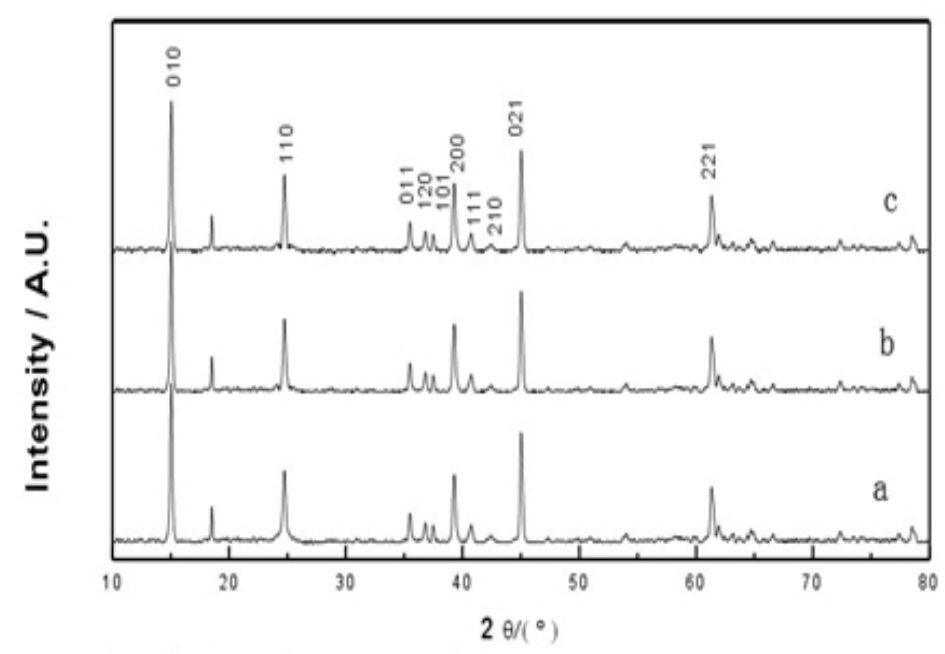

Fig.1 Materials XRD diagram

Picture 1 is XRD's picture of material. And a b v c are the XRD's atlas of $\mathrm{LiMn}_{0.92} \mathrm{Ni}_{0.08} \mathrm{O}_{2}$ $\mathrm{LiMn}_{0.93} \mathrm{Ni}_{0.07} \mathrm{O}_{2} \mathrm{LiMn}_{0.94} \mathrm{Ni}_{0.06} \mathrm{O}_{2}$ respectively. It can be seen from the picture that all the materials have the Li2MnO3 and other impurities diffraction maximum didn't occur. That means the effect of doping is good and the production of crystal lattice is pretty fine. 
Table 1 The unit cell parameters of materials

\begin{tabular}{cccc}
\hline $\mathrm{LiMn}_{1-\mathrm{x}} \mathrm{Ni}_{\mathrm{x}} \mathrm{O}_{2}$ & $\mathrm{a}(\mathrm{nm})$ & $\mathrm{c}(\mathrm{nm})$ & fwhm \\
\hline 0.06 & 0.2808 & 0.4579 & 0.330 \\
\hline 0.07 & 0.2807 & 0.4578 & 0.228 \\
\hline 0.08 & 0.2806 & 0.4577 & 0.197 \\
\hline
\end{tabular}

Table 1 is for the unit cell parameters $\mathrm{LiMn}_{1-\mathrm{x}} \mathrm{Ni}_{\mathrm{x}} \mathrm{O}_{2}$ and (110) crystal plane half width, Croguennec et al. ${ }^{[4,5]}$ reports the relationship between stacking fault and half width, table 1 shows the changing tendency of peak surface at about $25^{\circ}$. In contrast to the data without $\mathrm{Ni}^{2+} \mathrm{LiMnO}_{2}$, the material amorphous surface width becomes small after changing, which shows the stacking fault is reduced, the order of material is enhanced, the chaos of material is decreased, and with the increase of doping amount, this trend is more obvious

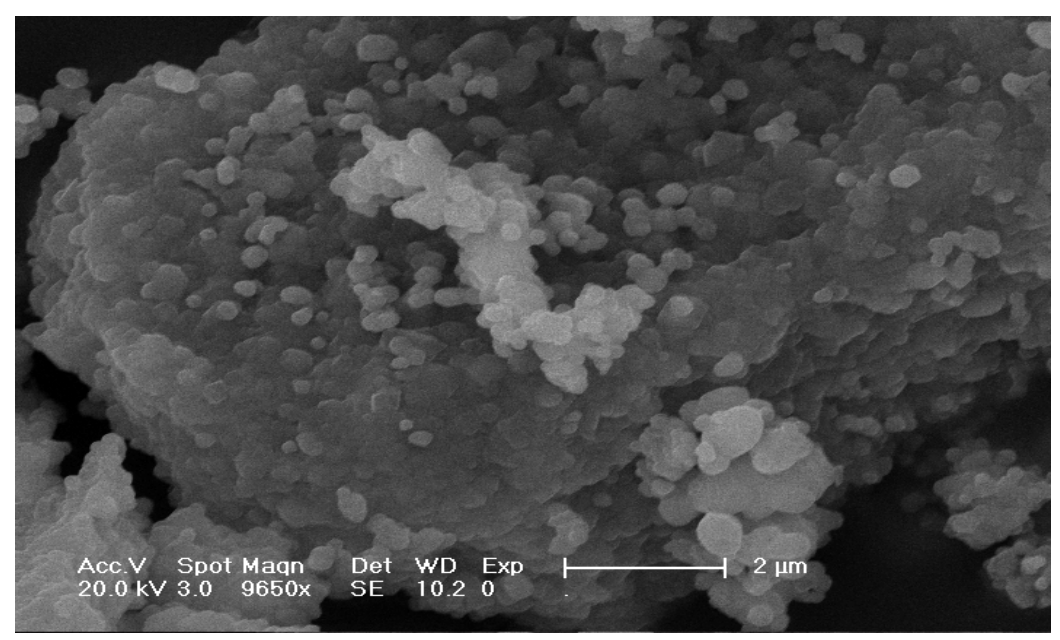

( a )

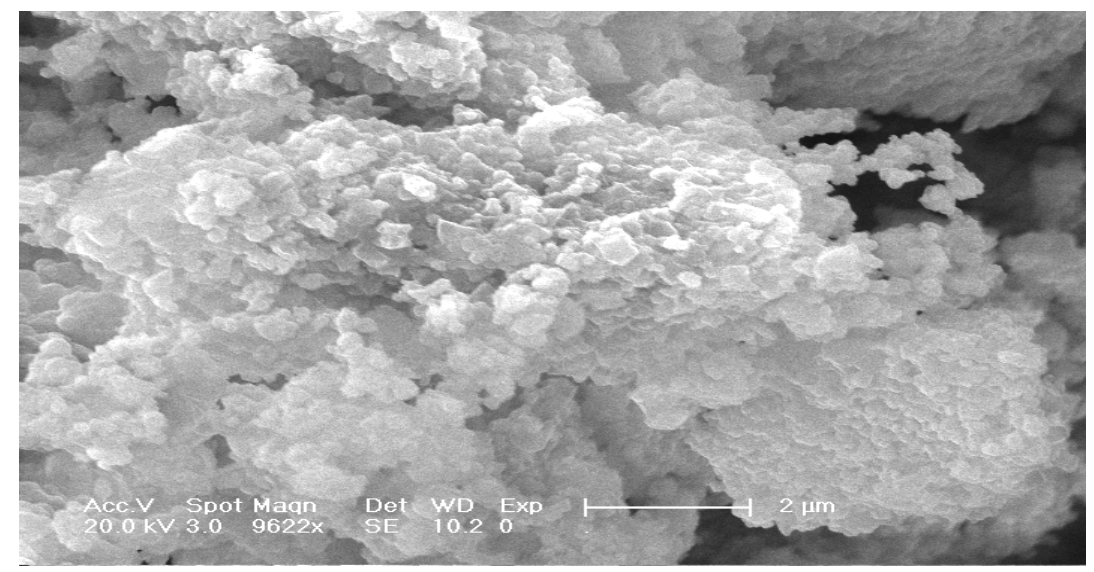

( b ) 


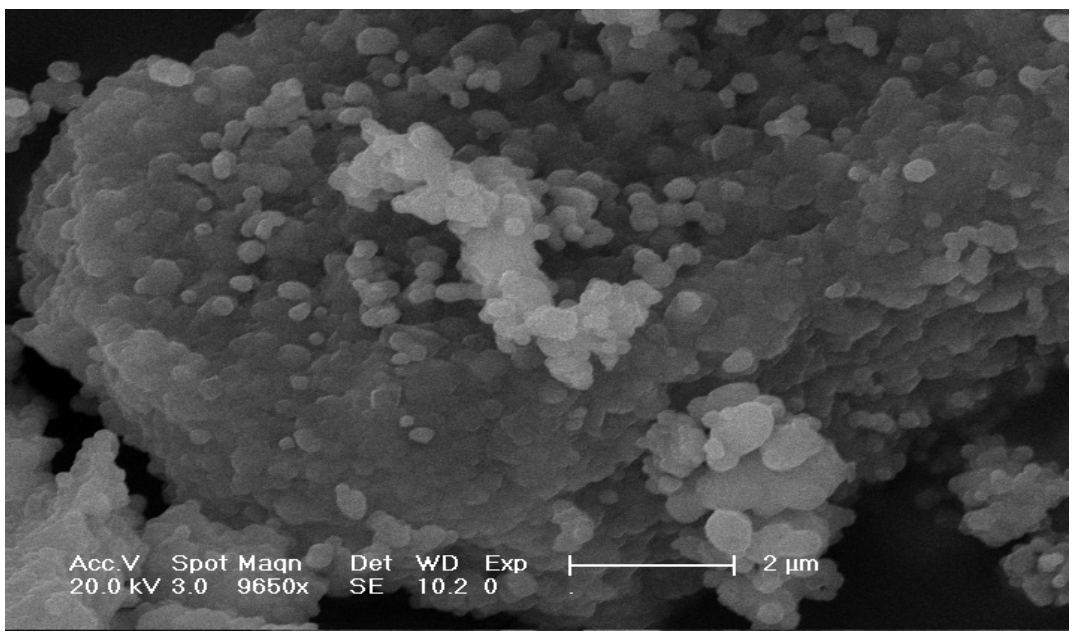

(c)

Fig.2 SEM chart of $\mathrm{LiMn}_{1-\mathrm{x}} \mathrm{Ni}_{\mathrm{x}} \mathrm{O}_{2}$

Figure 2 is the SEM photograph of LiMn1-xNixO2, where a, b, c are the SEM diagram of

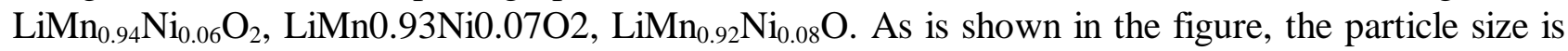
uneven, distribution is uneven; $\mathrm{B}$ being dense, not conducive to the ion deintercalation; $\mathrm{C}$ diagram shows even particle size, distribution is more ordered.

Charge discharge tests on materials, materials of $\mathrm{LiMn}_{0.94} \mathrm{Ni}_{0.06} \mathrm{O}_{2}, \mathrm{LiMn} 0.93 \mathrm{Ni0.07 \textrm {O } 2}$ and $\mathrm{LiMn}_{0.92} \mathrm{Ni}_{0.08} \mathrm{O}_{2}$, the initial discharge capacity were $48 \mathrm{mAh} / \mathrm{g}, 55 \mathrm{mAh} / \mathrm{g}, 56 \mathrm{mAh} / \mathrm{g}$, expressed as $\mathrm{Ni}$ incorporation amount bigger, lithium manganese oxide first charge discharge capacity is greater.

Figure 3 is a diagram of the cycle performance of materials. As can be seen, a is the material discharge curves of $\mathrm{LiMn}_{0.93} \mathrm{Ni}_{0.07} \mathrm{O}_{2}$, B is the material discharge curves of $\mathrm{LiMn}_{0.92} \mathrm{Ni}_{0.08} \mathrm{O}_{2}, \mathrm{C}$ is the material discharge curve of $\mathrm{LiMn}_{0.94} \mathrm{Ni}_{0.06} \mathrm{O}_{2}$.

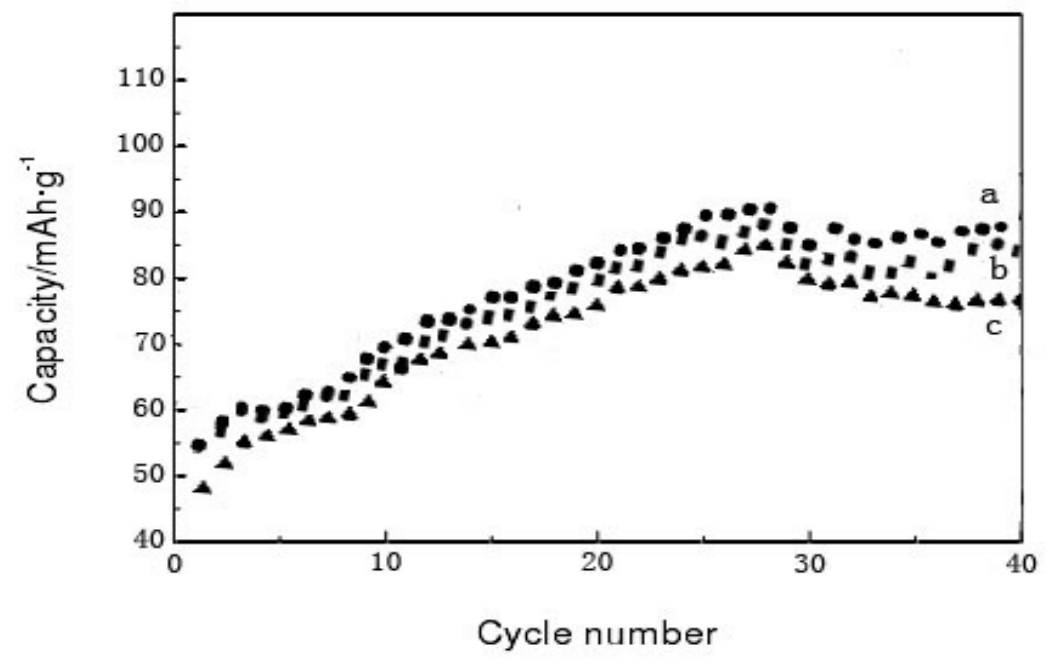

Fig. 3 the cyclic capacity chart

With the incorporation of $\mathrm{Ni}$ ions into material LiMn1-xNixO2, the impact changes on the cathode materials, $\mathrm{Ni}$ ion replaces parts of $\mathrm{Mn}$ ion, this has some inhibitory effect to Jahn-Teller. LiMn0.94Ni0.06O2 in the fortieth cycle has the discharge capacity of 74.2mAh/g, LiMn0.93Ni0.07O2 in the fortieth $87.3 \mathrm{mAh} / \mathrm{g}, \mathrm{LiMn} 0.92 \mathrm{Ni} 0.08 \mathrm{O} 2$ in the fortieth $84.5 \mathrm{mAh} / \mathrm{g}$. LiMn0.92Ni0.08O2 after 28 cycles, the discharge specific capacity decreased, the stability of the material also decreased, the discharge specific capacity of Ni doped ratio is not the higher the better, in order to improve the material specific capacity and ensure the the stability of the material, nickel incorporation at 0.7 is better than the other two proportion. 


\section{Conclusions}

Doping is a method of improving the performance of cathode materials, stacking faults in the presence of $\mathrm{Ni}^{2+}$ is extremely prominent ${ }^{[6]}$. modification is to reduce or even eliminate this phenomenon.

\section{Acknowledgements}

This work was supported by Jilin City Scientific and Technological Development Project (No.201162510), Foundation of Jilin Agricultural Science and Technology University for Youths (No. 2012130).

\section{References}

[1] L. Croguennec, P. Deniard, R. Brec, Electrochemical cyclability of orthorhombic $\mathrm{LiMnO}_{2}$ characterzation of cycled materias, J. Electrochem. Soc,1997,144:3323-3330

[2] Mengqiang $\mathrm{Wu}$, Ai Chen,Rongqing Xu,Yue Li , Low temperature hydrothermally synthesized nanocrystalline orthorhombic $\mathrm{LiMnO}_{2}$ cathode material for lithium-ion cells, Microelectronic Engineering, 2003, 66:180-185

[3] L. Croguennec, P. Deniard, R. Brec, A.Lecerf, Nature of stacking faults orthorhombic $\mathrm{LiMnO}_{2}, \mathrm{~J}$. Mater. Chem 1997, (3): 511-516

[4] Croguennec L,Deniard P,Brec R, et al. Electrochemical behavior of orthorhombic $\mathrm{LiMnO}_{2}$. Solid StateIon, 89 (1996)127 137.

[5] Croguennec L, Delmas C, Brec R, et al. Lithium batteries: a new tool in solid state chemistry.JInorganic Materials,1(1999) 11-19.

[6] Ritchie A.G. Recent developments and likely advances in lithium rechargeable batteries[J]. J. PowerSources. 2004, 136:285-289. 